\title{
Investigation of the Academic Motivations of the Students Studying Through Distance Education System in Terms of Some Variables / a Case Study of Sakarya University
}

\author{
Dr. Engin ÖMEROĞLU, Dr. Fikri KELEŞOĞLU \\ ${ }^{1}$ Lecturer, Department of Turkish Language, Sakarya University, Sakarya, Turkey. \\ ${ }^{1}$ Guidance and Research Center Directorate of Adapazari, Sakarya, Turkey.
}

\begin{abstract}
Motivation is one of the important elements for the sustainability of a behaviour. One condition of learning is that it leaves a permanent mark. One of the main references that will ensure this permanence in distance education is the academic performance of individuals. In this research, the students' academic motivations regarding online courses (virtual classes), who study through distance education system in some departments of Sakarya University were examined according to some variables, and the reasons for the low attendance rates in online courses (virtual classes) were investigated. The universe of the research consisted of students who studied at Sakarya University through distance education system while the study sample consisted of 660 students selected by random sampling method. Questionnaires and scales were delivered to the sample group via email. In the research, the "Academic Motivation Scale", adapted to Turkey by Karagüven (2012) and the questionnaire prepared by the researchers, asking about some demographic data were used, and the data obtained were analyzed with SPSS software. In this context, the results obtained from the research are as follows: It was observed that there was a significant difference between the lower dimensions of academic motivation levels and the gender, age, marital and employment status variables of the students who continued their education through online courses by distance education method at Sakarya University. It was found that there were no significant differences between some subdimensions of academic motivation and variables. At the end of the study, recommendations for gender, age, marital status and employment status were developed.
\end{abstract}

Keywords: Distance education, virtual classroom, online courses, intrinsic motivation, extrinsic motivation, amotivation.

\section{Introduction}

Today's developments in information and technology have also been reflected in the education system. As a result of new searches and requirements in education, the introduction of computers in the educationtraining process has led to the emergence of the distance education system via Internet (Horzum, 2003).

The first application of distance education in the world was carried out via mail in 1728 in the United States (İşman, 2011). The concept of Distance Education was first used at the University of Wisconsin in 1892 (Kaya et al., 2002). Today, education is carried out by distance education system in many countries, especially in the United States, Canada, Australia, England, etc. (Abazaoğlu and Umurhan, 2015).

The first Distance Education application in Turkey was started in 1956 at Ankara University and later in 1960 with the name "Education By Mail" under the Ministry of National Education. In 1974, Education By Mail Center was established within the Ministry of Education and continued its activities (Kaya, 2002).

Multimedia tools and presentation systems make it difficult to define distance education. Nevertheless, it can be defined as "the organization and conduct of teaching-learning activities without the need for the instructor and the student to be in the same confined space physically" (Gökdağ, 1986). "It is the activities carried out 
by using an integrated system of short-term face-to-face education with specially prepared written materials and mass communication programs, regardless of the age, time, place, method, aims and similar limitations of traditional educational practices" (Hızal, 1983). According to İşman (2011: 16), distance education is a model of education system in which the instructor and the student do not have to be in the same place and the educational activities are carried out by means of information communication technologies. The most obvious common point in the definitions of distance education is the separation of the instructor and student, whether it is written, visual, audio or computer-based or not (Kaya, 2002). This separation is one of the critical points that positively or negatively affects the motivation of both the student and the instructor (Begimbetova, 2015). This research is assumed to be important in determining students' attitudes and motivations in academic processes related to distance education, and determining the variables that affect processes.

Today's distance education system is now more qualified with information technologies and takes place in the form of teleconferencing and via Internet applications (İşman, 2011). Even though distance education is carried out in a more qualified form with the developing technology, the fact that education phenomenon and human motives can be influenced by their own dynamic structure and different variables is reflected in the continuation of distance education and the learning motivations of the students (Mullins, 2002; Begimbetova, 2015). The high level of motivation on the other hand ensures high level of learning as desired (Senemoğlu, 2007). This makes the level of motivation an element that is both important and necessary in the learning process.

\section{Purpose of the Research}

At Sakarya University, students who take some courses via Internet by distance education system have very low attendance to online courses (virtual classes). The purpose of the research is to demonstrate the relationship between academic motivation and some variables that are thought to have an effect on nonattendance of students to online courses, and develop suggestions that will contribute to educational processes accordingly.

\section{Research Problem}

Although the distance education model in Turkey has become very widespread, the majority of students who study at Sakarya University and take their courses through distance education do not attend the online courses, and do not follow/watch these courses in the simultaneous Internet environment. Are there different variables that affect the academic motivation of students not to follow the online courses?

\section{Subproblems}

Is there a significant difference between students' academic motivation and gender?

Is there a significant difference between students' academic motivation and age?

Is there a significant difference between students' academic motivation and marital status?

Is there a significant difference between students' academic motivation and employment status?

\section{Method}

This research is a descriptive study and was conducted by the survey method. The survey method aims to collect data to determine the various characteristics of a group (Büyüköztürk et al. 2009). This study was carried out based on the data obtained in the research and interpreted according to the information in the current literature.

The universe of the study consisted of students studying at Sakarya University and taking their courses through distance education. The sample of the study consisted of 660 students who were selected by random sampling method. Questionnaires and scales were delivered to the sample group via email.

In the research, the Academic Motivation Scale, which was adapted to Turkey by Karagüven (2012), validity and reliability studies of which were conducted, and questionnaire prepared by the researchers were used, and the data obtained were analyzed using SPSS software.

The Kolmogorov-Smirnov normality test was applied to determine whether the scores of the students who made up the sample group were normally distributed. As a result of the test, it was seen that the data were 
not normally distributed. Therefore, Mann-Whitney U Test was used to determine whether there were differences in the distributions of two groups (gender, marital status, etc.), and Kruskal-Wallis H Test was used in groups with more than two variables (age, employment status, etc.).

Table 1: Academic Motivation Scale Normality Test Results

\begin{tabular}{|l|c|c|c|}
\hline \multirow{2}{*}{} & \multicolumn{3}{|c|}{ Kolmogorov-Smirnov } \\
\cline { 2 - 4 } & Statistic & df & Sig. \\
\hline Intrinsic Motivation to Know & .173 & 660 & .000 \\
\hline Intrinsic Motivation to Accomplish & .083 & 660 & .000 \\
\hline Intrinsic Motivation to Experience Stimulation & .084 & 660 & .000 \\
\hline Extrinsic Motivation Identified Regulation & .161 & 660 & .000 \\
\hline Extrinsic Motivation Introjected Regulation & .091 & 660 & .000 \\
\hline Extrinsic Motivation External Regulation & .152 & 660 & .000 \\
\hline Amotivation & .269 & 660 & .000 \\
\hline
\end{tabular}

\section{Results}

In this part of the research, results will be given as to whether the hypotheses formed by passing the data collected from the sample group through the analysis process after the applications made by the researcher were true or false. In the data analysis, the demographic information, i.e. the data obtained from the information form, will be compared with the values obtained from the scale and the results of statistical analysis will be reflected by using appropriate techniques.

Table 2.Comparison of the Scores of the Sample Group from the Gender Variables and Sub-dimensions of Academic Motivation Scale

\begin{tabular}{|c|c|c|c|c|c|c|}
\hline Dimensions & Groups & $\mathbf{N}$ & $\begin{array}{l}\text { Mean } \\
\text { Rank }\end{array}$ & $\begin{array}{l}\text { Rank } \\
\text { Sum }\end{array}$ & $\mathbf{U}$ & $\mathbf{P}$ \\
\hline \multirow{2}{*}{$\begin{array}{l}\text { Intrinsic } \\
\text { Motivation to } \\
\text { Know }\end{array}$} & Female & 78 & 411.67 & 32110.50 & \multirow[t]{2}{*}{16366.0} & \multirow[t]{2}{*}{.000} \\
\hline & Male & 582 & 319.62 & 186019.50 & & \\
\hline \multirow{2}{*}{$\begin{array}{l}\text { Intrinsic } \\
\text { Motivation to } \\
\text { Accomplish }\end{array}$} & Female & 78 & 427.02 & 33307.50 & \multirow[t]{2}{*}{15169.5} & \multirow[t]{2}{*}{.000} \\
\hline & Male & 582 & 317.56 & 184822.50 & & \\
\hline \multirow{2}{*}{$\begin{array}{l}\text { Intrinsic } \\
\text { Motivation to } \\
\text { Experience } \\
\text { Stimulation }\end{array}$} & Female & 78 & 395.00 & 30810.00 & \multirow[t]{2}{*}{17667.0} & \multirow[t]{2}{*}{.001} \\
\hline & Male & 582 & 321.86 & 187320.00 & & \\
\hline \multirow{2}{*}{$\begin{array}{l}\text { Extrinsic } \\
\text { Motivation } \\
\text { Identified } \\
\text { Regulation }\end{array}$} & Female & 78 & 452.46 & 35292.00 & \multirow[t]{2}{*}{13185.0} & \multirow[t]{2}{*}{.000} \\
\hline & Male & 582 & 314.15 & 182838.00 & & \\
\hline \multirow{2}{*}{$\begin{array}{l}\text { Extrinsic } \\
\text { Motivation } \\
\text { Introjected } \\
\text { Regulation }\end{array}$} & Female & 78 & 420.10 & 32767.50 & \multirow[t]{2}{*}{15709.5} & \multirow[t]{2}{*}{.000} \\
\hline & Male & 582 & 318.49 & 185362.50 & & \\
\hline \multirow{2}{*}{$\begin{array}{l}\text { Extrinsic } \\
\text { Motivation } \\
\text { External } \\
\text { Regulation } \\
\end{array}$} & Female & 78 & 400.02 & 31201.50 & \multirow[t]{2}{*}{17275.5} & \multirow[t]{2}{*}{.001} \\
\hline & Male & 582 & 321.18 & 186928.50 & & \\
\hline \multirow[t]{2}{*}{ Amotivation } & Female & 78 & 370.25 & 28879.50 & \multirow[t]{2}{*}{19597.5} & \multirow[t]{2}{*}{.034} \\
\hline & Male & 582 & 325.17 & 189250.50 & & \\
\hline
\end{tabular}

Mann-Whitney U Test was used to determine the difference between the scores that individuals in the sample group received from "Academic Motivation Scale" according to the "Gender" variable. There 
were significant differences between the sub-dimensions: Intrinsic Motivation to $\operatorname{Know}(\mathrm{U}=16366.5 ; \mathrm{p}$ $=.000 ; \mathrm{p}$ <0.05); 'Intrinsic Motivation to Accomplish' ( $\mathrm{U}=15169.5 ; \mathrm{p}=.000 ; \mathrm{p} 0.05)$; Intrinsic Motivation to Experience Stimulation ( $\mathrm{U}=17667.0 ; \mathrm{p}=.001 ; \mathrm{p} 0.05)$; Extrinsic Motivation Identified Regulation $(\mathrm{U}=13185.0 ; \mathrm{p}=.000 ; \mathrm{p} 0.05)$; Extrinsic Motivation Introjected Regulation ( $\mathrm{U}=15709.5 ; \mathrm{p}=.000 ; \mathrm{p} 0.05)$; Extrinsic Motivation External Regulation ( $\mathrm{U}=17275.5$; $\mathrm{p}=.001$; $\mathrm{p} 0.05)$; amotivation $(\mathrm{U}=19597.5$; $\mathrm{p}=.034$; p0.05). In other words, gender variable significantly differentiates in all sub-dimensions of academic motivation.

Table 3.Comparison of the Scores of the Sample Group Received from the Academic Motivation Scale and its Sub-Dimensions

\begin{tabular}{|c|c|c|c|c|c|c|}
\hline Dimensions & Groups & $\mathbf{N}$ & $\begin{array}{l}\text { Mean } \\
\text { Rank }\end{array}$ & sd & $\mathbf{X}^{2}$ & $\mathbf{P}$ \\
\hline \multirow{5}{*}{$\begin{array}{l}\text { Intrinsic } \\
\text { Motivation to } \\
\text { Know }\end{array}$} & $18-20$ & 114 & 283.05 & \multirow[t]{5}{*}{4} & \multirow[t]{5}{*}{12.941} & \multirow[t]{5}{*}{.012} \\
\hline & $21-25$ & 126 & 311.96 & & & \\
\hline & $26-30$ & 108 & 357.33 & & & \\
\hline & $31-40$ & 234 & 343.33 & & & \\
\hline & Over 40 & 78 & 354.15 & & & \\
\hline \multirow{5}{*}{$\begin{array}{l}\text { Intrinsic } \\
\text { Motivation to } \\
\text { Accomplish }\end{array}$} & $18-20$ & 114 & 315.62 & \multirow[t]{5}{*}{4} & \multirow[t]{5}{*}{10.342} & \multirow[t]{5}{*}{.035} \\
\hline & $21-25$ & 126 & 327.04 & & & \\
\hline & $26-30$ & 108 & 383.71 & & & \\
\hline & $31-40$ & 234 & 319.65 & & & \\
\hline & Over 40 & 78 & 316.71 & & & \\
\hline \multirow{5}{*}{$\begin{array}{l}\text { Intrinsic } \\
\text { Motivation to } \\
\text { Experience } \\
\text { Stimulation }\end{array}$} & $18-20$ & 114 & 311.83 & \multirow[t]{5}{*}{4} & \multirow[t]{5}{*}{4.383} & \multirow[t]{5}{*}{.357} \\
\hline & $21-25$ & 126 & 336.25 & & & \\
\hline & $26-30$ & 108 & 314.79 & & & \\
\hline & $31-40$ & 234 & 332.60 & & & \\
\hline & Over 40 & 78 & 363.96 & & & \\
\hline \multirow{5}{*}{$\begin{array}{l}\text { Extrinsic } \\
\text { Motivation } \\
\text { Identified } \\
\text { Regulation }\end{array}$} & $18-20$ & 114 & 348.93 & \multirow[t]{5}{*}{4} & \multirow[t]{5}{*}{60.347} & \multirow[t]{5}{*}{.000} \\
\hline & $21-25$ & 126 & 357.64 & & & \\
\hline & $26-30$ & 108 & 409.00 & & & \\
\hline & $31-40$ & 234 & 313.77 & & & \\
\hline & Over 40 & 78 & 201.21 & & & \\
\hline \multirow{5}{*}{$\begin{array}{l}\text { Extrinsic } \\
\text { Motivation } \\
\text { Introjected } \\
\text { Regulation }\end{array}$} & $18-20$ & 114 & 317.04 & \multirow[t]{5}{*}{4} & \multirow[t]{5}{*}{37.951} & \multirow[t]{5}{*}{.000} \\
\hline & $21-25$ & 126 & 388.07 & & & \\
\hline & $26-30$ & 108 & 389.21 & & & \\
\hline & $31-40$ & 234 & 302.10 & & & \\
\hline & Over 40 & 78 & 261.10 & & & \\
\hline \multirow{5}{*}{$\begin{array}{l}\text { Extrinsic } \\
\text { Motivation } \\
\text { External } \\
\text { Regulation }\end{array}$} & $18-20$ & 114 & 402.22 & \multirow[t]{5}{*}{4} & \multirow[t]{5}{*}{94.881} & \multirow[t]{5}{*}{.000} \\
\hline & $21-25$ & 126 & 395.21 & & & \\
\hline & $26-30$ & 108 & 349.46 & & & \\
\hline & $31-40$ & 234 & 306.88 & & & \\
\hline & Over 40 & 78 & 165.73 & & & \\
\hline \multirow[t]{5}{*}{ Amotivation } & $18-20$ & 114 & 411.93 & \multirow[t]{5}{*}{4} & \multirow[t]{5}{*}{107.399} & \multirow[t]{5}{*}{.000} \\
\hline & $21-25$ & 126 & 432.14 & & & \\
\hline & $26-30$ & 108 & 248.75 & & & \\
\hline & $31-40$ & 234 & 287.29 & & & \\
\hline & Over 40 & 78 & 290.12 & & & \\
\hline
\end{tabular}


The difference between the scores obtained from the sub-dimensions of the "Academic Motivation Scale" of the individuals in the sample group was examined with the Kruskal-Wallis H Test according to the "age" variable. There was a difference between sub-dimensions "Intrinsic Motivation to Know $\left[\chi^{2}(4)=12.941 ; p\right.$ $=.012 ; \mathrm{p}<0.05]$, Intrinsic Motivation to Accomplish $\left[\chi^{2}(4)=10.342 ; \mathrm{p}=.035 ; \mathrm{p} 0.05\right]$, Extrinsic Motivation Identified Regulation $\left[\chi^{2}(4)=60.347 ; p=000 ; p 0,05\right]$, Extrinsic Motivation Introjected Regulation $\left[\chi^{2}(4)=\right.$ 37.951; $\mathrm{p}=000 ; \mathrm{p} 0.05]$, Extrinsic Motivation External Regulation $\left[\chi^{2 \mathrm{nd}}(4)=94.881 ; \mathrm{p}=000 ; \mathrm{p} 0.05\right]$; amotivation $\left[\chi^{2}(4)=107.399 ; \mathrm{p}=000 ; \mathrm{p} 0.05\right] "$ and age levels of the sample group, but there was no significant difference between Intrinsic Motivation to Experience Stimulation $\left[\chi^{2}(4)=4.383 ; p=357 ; p 0.05\right]$.

Table 4.Comparison of Marital Status Variable with the Scores Of The Sample Group Received from the Sub-Dimensions of Academic Motivation Scale

\begin{tabular}{|c|c|c|c|c|c|c|}
\hline Dimensions & Groups & $\mathbf{N}$ & $\begin{array}{l}\text { Mean } \\
\text { Rank }\end{array}$ & $\begin{array}{l}\text { Rank } \\
\text { Sum }\end{array}$ & $\mathbf{U}$ & $\mathbf{P}$ \\
\hline \multirow{2}{*}{$\begin{array}{l}\text { Intrinsic } \\
\text { Motivation to } \\
\text { Know }\end{array}$} & Married & 303 & 339.93 & 102999.00 & \multirow[t]{2}{*}{51228.0} & \multirow[t]{2}{*}{236} \\
\hline & Single & 357 & 322.50 & 115131.00 & & \\
\hline \multirow{2}{*}{$\begin{array}{l}\text { Intrinsic } \\
\text { Motivation to } \\
\text { Accomplish }\end{array}$} & Married & 303 & 330.74 & 100213.50 & \multirow[t]{2}{*}{54013.5} & \multirow[t]{2}{*}{.976} \\
\hline & Single & 357 & 330.30 & 117916.50 & & \\
\hline \multirow{2}{*}{$\begin{array}{l}\text { Intrinsic } \\
\text { Motivation to } \\
\text { Experience } \\
\text { Stimulation }\end{array}$} & Married & 303 & 330.23 & 100060.50 & \multirow[t]{2}{*}{54004.5} & \multirow[t]{2}{*}{.973} \\
\hline & Single & 357 & 330.73 & 118069.50 & & \\
\hline \multirow{2}{*}{$\begin{array}{l}\text { Extrinsic } \\
\text { Motivation } \\
\text { Identified } \\
\text { Regulation } \\
\end{array}$} & Married & 303 & 307.96 & 93310.50 & \multirow[t]{2}{*}{47254.5} & \multirow[t]{2}{*}{.005} \\
\hline & Single & 357 & 349.63 & 124819.50 & & \\
\hline \multirow{2}{*}{$\begin{array}{l}\text { Extrinsic } \\
\text { Motivation } \\
\text { Introjected } \\
\text { Regulation }\end{array}$} & Married & 303 & 309.17 & 93679.50 & \multirow[t]{2}{*}{47623.5} & \multirow[t]{2}{*}{.008} \\
\hline & Single & 357 & 348.60 & 124450.50 & & \\
\hline \multirow{2}{*}{$\begin{array}{l}\text { Extrinsic } \\
\text { Motivation } \\
\text { External } \\
\text { Regulation }\end{array}$} & Married & 303 & 278.27 & 84315.00 & \multirow[t]{2}{*}{38259.0} & \multirow[t]{2}{*}{.000} \\
\hline & Single & 357 & 374.83 & 133815.00 & & \\
\hline \multirow[t]{2}{*}{ Amotivation } & Married & 303 & 268.29 & 81291.00 & \multirow[t]{2}{*}{35235.0} & \multirow[t]{2}{*}{.000} \\
\hline & Single & 357 & 383.30 & 136839.00 & & \\
\hline
\end{tabular}

Mann-Whitney U Test was used to determine the difference between the scores that individuals in the sample group received from "Academic Motivation Scale" according to the "Marital Status" variable. There were no significant differences between sub-dimensions "Intrinsic Motivation to Know (U=51228.0; $\mathrm{p}=.236 ; \mathrm{p}>0.05)$; 'Intrinsic Motivation to Accomplish' ( $U=54013.5 ; \mathrm{p}=.976 ; \mathrm{p}>0.05)$; Intrinsic Motivation to Experience Stimulation $(\mathrm{U}=54004.5 ; \mathrm{p}=.973 ; \mathrm{p}>0.05)$ ", but there was a significant difference between subdimensions "Extrinsic Motivation Identified Regulation ( $U=47254.5 ; \mathrm{p}=.005 ; \mathrm{p}>0.05)$; Extrinsic Motivation Introjected Regulation( $\mathrm{U}=47623.5 ; \mathrm{p}=.008 ; \mathrm{p}<0.05)$; Extrinsic Motivation External Regulation $(\mathrm{U}=38259.0$; $\mathrm{p}=.000 ; \mathrm{p} 0.05)$; amotivation $(\mathrm{U}=35235.0 ; \mathrm{p}=.000 ; \mathrm{p} 0.05)$.

Table 5.Comparison of Employment Status Variable with the Scores of the Sample Group Received from the Sub-Dimensions of "Academic Motivation Scale"

\begin{tabular}{|l|l|l|l|l|l|l|}
\hline Dimensions & Groups & N & Mean Rank & sd & $\mathbf{X}^{2}$ & $\mathbf{P}$ \\
\hline
\end{tabular}




\begin{tabular}{|c|c|c|c|c|c|c|}
\hline \multirow{4}{*}{$\begin{array}{l}\text { Intrinsic } \\
\text { Motivation } \\
\text { to Know }\end{array}$} & Public Official & 99 & 314.77 & \multirow[t]{4}{*}{3} & \multirow[t]{4}{*}{17.429} & \multirow[t]{4}{*}{.001} \\
\hline & Private Sector Employee & 369 & 353.39 & & & \\
\hline & $\begin{array}{l}\text { Working at his/her own } \\
\text { workplace }\end{array}$ & 75 & 330.02 & & & \\
\hline & Unemployed & 117 & 271.92 & & & \\
\hline \multirow{4}{*}{$\begin{array}{l}\text { Intrinsic } \\
\text { Motivation } \\
\text { to } \\
\text { Accomplish }\end{array}$} & Public Official & 99 & 324.27 & \multirow[t]{4}{*}{3} & \multirow[t]{4}{*}{9.669} & \multirow[t]{4}{*}{.022} \\
\hline & Private Sector Employee & 369 & 349.51 & & & \\
\hline & $\begin{array}{l}\text { Working at his/her own } \\
\text { workplace }\end{array}$ & 75 & 297.32 & & & \\
\hline & Unemployed & 117 & 297.08 & & & \\
\hline \multirow{4}{*}{$\begin{array}{l}\text { Intrinsic } \\
\text { Motivation } \\
\text { to } \\
\text { Experience } \\
\text { Stimulation }\end{array}$} & Public Official & 99 & 303.86 & \multirow[t]{4}{*}{3} & \multirow[t]{4}{*}{11.880} & \multirow[t]{4}{*}{.008} \\
\hline & Private Sector Employee & 369 & 350.09 & & & \\
\hline & $\begin{array}{l}\text { Working at his/her own } \\
\text { workplace }\end{array}$ & 75 & 336.38 & & & \\
\hline & Unemployed & 117 & 287.50 & & & \\
\hline \multirow{4}{*}{$\begin{array}{l}\text { Extrinsic } \\
\text { Motivation } \\
\text { Identified } \\
\text { Regulation }\end{array}$} & Public Official & 99 & 288.23 & \multirow[t]{4}{*}{3} & \multirow[t]{4}{*}{23.073} & \multirow[t]{4}{*}{.000} \\
\hline & Private Sector Employee & 369 & 361.46 & & & \\
\hline & $\begin{array}{l}\text { Working at his/her own } \\
\text { workplace }\end{array}$ & 75 & 278.66 & & & \\
\hline & Unemployed & 117 & 301.85 & & & \\
\hline \multirow{4}{*}{$\begin{array}{l}\text { Extrinsic } \\
\text { Motivation } \\
\text { Introjected } \\
\text { Regulation }\end{array}$} & Public Official & 99 & 311.68 & \multirow[t]{4}{*}{3} & \multirow[t]{4}{*}{9.777} & \multirow[t]{4}{*}{.021} \\
\hline & Private Sector Employee & 369 & 350.01 & & & \\
\hline & $\begin{array}{l}\text { Working at his/her own } \\
\text { workplace }\end{array}$ & 75 & 287.00 & & & \\
\hline & Unemployed & 117 & 312.77 & & & \\
\hline \multirow{4}{*}{$\begin{array}{l}\text { Extrinsic } \\
\text { Motivation } \\
\text { External } \\
\text { Regulation }\end{array}$} & Public Official & 99 & 267.68 & \multirow[t]{4}{*}{3} & \multirow[t]{4}{*}{53.396} & \multirow[t]{4}{*}{.000} \\
\hline & Private Sector Employee & 369 & 349.04 & & & \\
\hline & $\begin{array}{l}\text { Working at his/her own } \\
\text { workplace }\end{array}$ & 75 & 220.82 & & & \\
\hline & Unemployed & 117 & 395.50 & & & \\
\hline \multirow{4}{*}{$\begin{array}{l}\text { Amotivatio } \\
\text { n }\end{array}$} & Public Official & 99 & 332.41 & \multirow[t]{4}{*}{3} & \multirow[t]{4}{*}{27.211} & \multirow[t]{4}{*}{.000} \\
\hline & Private Sector Employee & 369 & 302.26 & & & \\
\hline & $\begin{array}{l}\text { Working at his/her own } \\
\text { workplace }\end{array}$ & 75 & 376.22 & & & \\
\hline & Unemployed & 117 & 388.65 & & & \\
\hline
\end{tabular}

The difference between the scores obtained from the sub-dimensions of the "Academic Motivation Scale" of the individuals in the sample group was examined with the Kruskal-Wallis $\mathrm{H}$ Test according to the "employment status" variable. There was a difference between the sub-dimensions "Intrinsic Motivation to $\operatorname{Know}\left[\chi^{2}(3)=17.429 ; \mathrm{p}=001 ; \mathrm{p}<0.05\right]$; Intrinsic Motivation to Accomplish $\left[\chi^{2}(3)=9.669 ; \mathrm{p}=022 ; \mathrm{p} 0.05\right]$; Intrinsic Motivation to Experience Stimulation $\left[\chi^{2}(3)=11.880 ; p=.008 ; p 0.05\right]$, Extrinsic Motivation Identified Regulation $\left[\chi^{2 \text { nd }}(3)=23.073 ; p=000 ; p 0.05\right]$, Extrinsic Motivation Introjected Regulation $\left[\chi^{2}(3)=\right.$ 9.777; $\mathrm{p}=.021 ; \mathrm{p} 0.05]$, Extrinsic Motivation External Regulation $\left[\chi^{2}(4)=53.396 ; \mathrm{p}=000 ; \mathrm{p} 0.05\right]$, amotivation $\left[\chi^{2}(3)=27.211 ; \mathrm{p}=000 ; \mathrm{p} 0.05\right] "$ and the employment status of the sample group.

\section{Discussion}

As a result of the research, it was observed that there was a significant difference between the lower dimensions of academic motivation levels and the gender, age, marital status and employment status variables of the students who received education in online classes by distance education method at Sakarya University. 
It was found that there was a significant difference between the gender of the students involved in the study and all the sub-dimensions of academic motivation level. Females' academic motivation levels were significantly higher than those of males. Examining the sub-dimensions, the highest mean rank of the females was the extrinsic motivation identified regulation sub-dimension, while this was amotivation subdimension for the males. This shows a clear separation of the behavioral references of males and females that is decisive in academic motivation. Other studies in the literature support these results (Aktan, 2012; Vansteenkiste et al., 2009; DemirGüdül, 2010; Ratelle et al., 2007;). Some research results indicate that there is no significant difference in academic motivation levels according to gender (Saracaloğlu, 2008; Demir and Ar1, 2013; Şahin and Çakar, 2011).

Examining the significance between the age variable and the sub-dimensions of academic motivation level, there is significant difference in all sub-dimensions except the intrinsic motivation to experience stimulation sub-dimension. When the mean rank of the sub-dimensions is taken into consideration, the motivation scores of individuals under 30 years of age increase while the motivation scores of individuals over 30 years of age decrease. This finding suggests that age is a decisive variable in academic motivation. Again, this significant difference can be interpreted as increasing responsibilities in daily life with the age advancement does not give much opportunity to one's academic studies, and in this case it can negatively affect the motivation of the person. Knowing that needs and expectations are decisive in motivation (Şimşek et al., 2010) facilitates this interpretation. The findings of the researchers such as Hartlap (2007), Çakır (2006), Neisi and Yamini (2010) confirm the results obtained.

According to another finding obtained from the research, some sub-dimensions of academic motivation differ significantly according to marital status. Examining the sub-dimensions within themselves, there was no significant difference between the sub-dimensions of the intrinsic motivation and the marital status. The significant differences were all seen in the sub-dimensions of extrinsic motivation and the amotivation. This suggests that marital status is not decisive in terms of internal dynamics of individuals in academic processes. People's life after marriage, individual, psycho-social and economic conditions have not been distinctive through the marital status variable, for them to shape and structure their own academic work. Ensuring the persistence of motivation depends on the creation and protection of environmental conditions (Ivancevich and Matteson, 2002). Studies showing that intrinsic motivation is more effective than extrinsic motivation have made the findings of this study more meaningful for those who continue their educational life after marriage. Individuals with low intrinsic motivation are quite far from struggling with problems, and competing. The motivation of individuals who do not feel any excitement in terms of learning behaviors towards education and academic studies is far from being a trigger (Eggen and Kauchak, 1997; Karataş and Erden, 2012; Ryan and Deci, 2000). The fact that the mean ranks of the extrinsic motivation subdimensions of the individuals involved in the study were high, especially in singles, suggests that extrinsic motivation is not as effective in the educational processes of those who are married as it is in singles.

When the significance between employment status variable and sub-dimensions of academic motivation is examined, a significant difference is observed between all the sub-dimensions and employment status. This shows that the employment status has a direct decisive effect on the educational life of individuals, and is an important dynamic that affects their motivation. When we look at the mean ranks of the private sector employee, which is one of the employment statuses in the sub-dimensions of academic motivation, it is noteworthy that this is high in both intrinsic motivation sub-dimensions and extrinsic motivation subdimensions. This shows that both external and internal factors are effective in the educational lives of private sector employees. While this may be interpreted as the fact that the certificate, diploma or certificate to be obtained at the end of the education/training may constitute an alternative for job guarantee, considering that the private sector has lower job guarantee, it can also be interpreted as the fact that awards and promotions in the private sector increase the academic motivation which is decisive in the educational life of the individuals as a result of arousing their interests, needs and curiosities. Different research results support these findings and interpretations (Mahaney and Lederer, 2006; Dündar et al., 2006; Wiersma, 1992; Brislin et al., 2005).

All of these results shed light on the problematic situation of the students in the virtual classrooms regarding following lessons and course attendance. The significance of the difference in all sub-dimensions of academic motivation, which is discussed through gender, age, marital status and employment status 
variables, contributes both to learners, instructors and system builders in structuring distance education processes.

\section{Recommendations}

Based on the findings of the study, the following recommendations were developed:

1. In this study, we found significant differences in the sub-dimension of extrinsic motivation-recognition, one of the sub-dimensions of academic motivation for females, whereas a significant difference was observed in the amotivational sub-dimension for males. If these findings can be studied qualitatively in another study, the effect of intrinsic and extrinsic motivation to be a reference in learning behaviors regarding other sub-dimensions will be seen more clearly.

2. Although there is a significant difference between academic motivation and age in the research findings, it is seen that the mean ranks of individuals over thirty years decrease. Therefore, in order to maintain the motivation necessary for the success and ideals of individuals in their educational lives in advanced ages, taking realistic and applicable demands and requirements from individuals and integrating them into the structure of the distance education system will positively affect the motivation of individuals in the education processes.

3. It was seen that intrinsic motivation did not make a significant difference in the findings related to marital status, and it was not a decisive dynamic in academic motivation. However, different studies have shown that extrinsic motivation accompanying intrinsic motivation is effective and decisive in learning behaviours. In this context, increasing the intrinsic motivation of male and female distance education students will also contribute positively to their academic motivations. For this purpose, personal / social guidance services should be provided to individuals at a higher level and their accessibility should be ensured.

4. The study showed that there is a significant difference between employment status and academic motivation. The fact that the mean ranks of private sector employees' employment status are higher compared to other employment status is quite noteworthy. In order to increase the academic motivation of individuals with other employment status, educational and professional studies should be emphasized. Furthermore, given the high mean ranks for private sector employees as a result of job losing risk, this is not acceptable on the basis of human rights. The number of initiatives and activities in which job guarantee is offered together and which increase internal and external motivation should be increased. This will increase the academic motivation of distance education students as well as their welfare.

\section{References}

[1] Abazaoğlu İ, Umurhan H (2015) Distance education and promotion factors to the faculty of distance education. Journal of Research in Education and Teaching 4 (4): 353-363.

[2] Aktan S (2012) Relationship between the academic success, self-regulating learning skills, and motivations of 5th grade students and teaching styles of teachers. Unpublished Master's Thesis, Turkey: Balikesir University.

[3] Begimbetova K (2015) Satisfactory level of teachers and students in distance learning. M. Sc. Thesis, Turkey: Gazi Unıversity.

[4] Brislin RW, Kabigting F, Macnab B, Zukis B, Worthley R (2005) Evolving perceptions of japanese workplace motivation. International Journal of Cross Cultural Management 5(1): 87103. https://doi.org/10.1177/1470595805050829

[5] Büyüköztürk Ş, Kılıç Çakmak E, Akgün ÖE, Karadeniz Ş, Demirel F (2009) Bilimsel araştırma yöntemleri. Ankara: Pegem Publishing.

[6] Çakır E (2006) Depression and motivation levels of students who are educating in Anatolian teacher training figh schools. Unpublished Master's Thesis, Turkey: Sakarya University.

[7] Demir Güdül M (2015) The relationship between university students' academic motivation profiles and psychological needs, academic procrastination and life satisfaction. $\mathrm{PhD}$ Thesis, Turkey: Anadolu University

[8] Demir M K, Ar1 E (2013) Assessing levels of academic motivation of preservice teachers in terms of various variables. Journal of Theory and Practice in Education 9 (3): 265-279. 
[9] Dündar S, Özutku H, Taşpınar F (2007) The effects of intrinsic and extrinsic motivation tools on employees' motivations: an empirical investigation. Gazi University Journal of Commerce \& Tourism Education Faculty (2): 105-119.

[10] Eggen P, Kauchak D (1997) Educational psychology windows on classrooms. New Jersey: Prentice-Hall Inc.

[11] Ergin A, Karataş H. (2018) Achievement-oriented motivation levels of university students. Hacettepe University Journal of Education. 33 (4): 868-887. Doi:10.16986/HUJE.2018036646

[12] Gökdağ D (1986) Printed materials in distance education (The case of Open Education Faculty). Eskişehir: Anadolu University Open Education Faculty Publications No 54.

[13] Hartlap S (2007) Evulationoffactors that affect academic succesacording to academics and student in hand crafts education program in profession high schollwithhout examination. Unpublished Master's Thesis, Turkey: Gazi University.

[14] Hizal A (1983) Distance education processes and written materials. Ankara: Ankara University Faculty of Educational Sciences Publications No 122.

[15] Horzum MB (2003) Ideas of lectures about internet based education (Sakarya university examples). Unpublished Master's Thesis, Turkey: Sakarya University.

[16] Ivancevich MJ, Matteson MT (2002) Organizational behavior and management. 6.b. New York: McGraw- Hill Higher Education.

[17] İşmanA (2011) Distance education. (4. Edition) Ankara: PegemAkademi.

[18] Karagüven H (2012) The adaptation of academic motivation scale to turkish. Educational Sciences: Theory and Practice 12 (4): 2599-2620.

[19] Karataş H Erden M (2012) Bilingual equivalence, validity and reliability of academic motivation scale. E-Journal of New World Sciences Academy (Newwsa) 7 (4): 983-1003. Doi: $10.12739 / 10.12739$

[20] Kaya Z (2002) Distance education. Ankara: Pegem A Publications.

[21] Kaya Z, Erden O, Çakır H, Bağırsakçı NB (2002) Preparation of web-based presentation of distance education needs unit in the basics of distance education course. The Turkish Online Journal of Educational Technology - TOJET July ISSN: 1303-6521 3 (3): 165-175.

[22] Mahaney RC, Lederer AL (2006) The effect of intrinsic and extrinsic rewards for developers on information systems project success, Project Management Journal, 37(4), 42-54. https://doi.org/10.1177/875697280603700405

[23] Neisi S, Yamini M (2010) Relationship between self-esteem, achievement motivation, flca and efllearners academic performance. Journal of Education and Psychology 4 (2): 153-166.

[24] Ratelle CF, Guay F, Vallerand RJ, Larose S, Senecal C (2007) Autonomus, controlled veamotived types of academic motivation: A person-oriented analysis. Journal of Educational Psychology 99 (4): 734-746. Doi: 10.1037/0022-0663.99.4.734

[25] Ryan RM, Deci EL (2000) Intrinsic and extrinsic motivations: classic definitions and new directions. Contemporary Educational Psychology (25): 54-67. Doi:10.1006/ceps.1999.1020

[26] Saracaloğlu AS (2008) The relationship between post graduate students' academic motivation level, research anxiety and attitudes with their research competence. YüzüncüYıl University Journal of Education (2): 179-208.

[27] Senemoğlu N (2007) Development, learning and teaching: From theory to practice. Ankara: Gönül Printing.

[28] Şahin H, Çakar E (2011) The effects of students' academic motivation and students' learning strategies on students' success. The Journal of Turkish Educational Sciences 9 (3): 519-540.

[29] Şimşek M Ş, A kgemci T, Çelik A (2010) Behavioural sciences. Ankara: Gazi Bookstore.

[30] Vansteenkiste M, Sierens E, Soenes E, Luyckx K, Lens W (2009) Motivational profiles from a self-determination perspective: the quality of motivation matters. Journal of Educational Psychology 101 (3): 671-688. Doi:10.1037/a0015083

[31] Wiersma, UJ (1992) The effects of extrinsic rewards in intrinsic motivation: a meta analysis. Journal of Occupational and Organizational Psychology 65 (2): 101-114. https://doi.org/10.1111/j.2044-8325.1992.tb00488.x 